\title{
Criminal Act of Sexual Gratification: Fiqh Jināyah and Positive Law Perspective
}

\author{
Nadea Lathifah Nugraheni \\ Wuhan University China \\ e-mail: nugraheninadealathifah@yahoo.co.id
}

\begin{abstract}
This paper describes the concept of sexual gratification based on positive legal views in Indonesia and fiqh jināyah. This type of qualitative research with the method of collecting library data is also normative in looking at and approaching cases of sexual gratification. This study uses several approaches, including case, comparison, and conceptual approaches. The government has regulated the Law Number. 31 of 1999 which has been updated by Law Number. 20 of 2001 on combating corruption. Moreover, it is stated in Article 12 B that explains matters including gratuities, such as money, goods, commissions, checks, travel tickets and other public facilities. Basically, the sanction of sexual gratification has fulfilled government regulations but has not yet been applied. Thus, it is necessary to reform the law of sexual gratification in Indonesia. The theory of Mukhtalath in Islamic law can be an alternative solution to cases of sexual gratification. The synchronicity of the role of the government and the clear rules and regulations relating to cases of sexual gratuity are urgently needed to achieve justice and legal validity.
\end{abstract}

\section{[]}

Tulisan ini mendeskripsikan konsep gratifikasi seksual berdasarkan pandangan hukum positif di Indonesia dan fiqh jināyah. Penelitian ini berjenis kualitatif dengan metode pengumpulan data kepustakaan juga bersifat normatif dalam memandang dan melakukan pendekatan terhadap kasus gratifikasi seksual. Penelitian ini menggunakan beberapa pendekatan, diantaranya pendekatan kasus, perbandingan dan konseptual. Pemerintah telah mengatur UU Nomor. 31 Tahun 1999 yang telah diperbaharui oleh UU Nomor. 20 tahun 2001 tentang pemberantasan korupsi. Terlebih tercantum dalam pasal 12 B yang menjelaskan hal-hal yang termasuk gratifikasi, seperti, uang, barang, komisi, check, tiket perjalanan dan fasilitas umum lainya. Pada dasarnya sanksi gratifikasi seksual telah memenuhi aturan pemerintah, akan tetapi belum diaplikasikan. Dengan demikian perlu pembaharuan terhadap hukum gratifikasi seksual di Indonesia. Teori tentang Mukhtalath dalam hukum islam dapat menjadi alternatif solusi akan kasus gratifikasi seksual. sinkronisitas peran pemerintah dan jelasnya aturan perundang-undangan terkait kasus gratifikasi seksual sangat dibutuhkan demi tercapainya keadilan dan keabsahan hukum.

Keywords: classification crimes; sexual gratification; fiqh jināyah; positive law 


\section{Introduction}

Nowadays, the most crucial problems in Indonesia is corruption. There are many definitions of corruption. Corruption is taken from the Greek language. Corruption has meant all of the damaging deeds. In Black's Law Dictionary, corruption is an intentional act to give illegal beneficial for himself or the people around him through his position or authority. ${ }^{1}$ According to Syed Husein Alatas, corruption is the abusing trust. ${ }^{2}$

Corruption divided into many forms and ranges from trivial to monumental. Syed Husein Alatas divided corruption into 7 types they are transactive corruption, exsortif corruption, investive corruption, nepotistic corruption, otogenic corruption, supportive corruption, and defensive corruption.

One corruption form is gratification. The word gratification on Kamus Besar Bahasa Indonesia is giving and accepting money which is not related to their salary. ${ }^{3}$ Gratification has been mentioned in Article 12 B and 12 Number 20 The year 2001 about criminal act of corruption. Gratification is giving in the wider sense of definition which involves money, goods, discount, commission, a loan with no interest, travel cheque, overnight facility, tourism journey, free medication, and other facilities. Gratification may be received within the host country or the foreign country and can be given by electronic or by manual. In the form above, gratification includes of transactive corruption.

As a new form of gratification crime, "sexual gratification "has become increasingly intense in recent years. The sexual gratification is a great harm to the society. There are many cases, which showed us about sexual gratification. Moreover, there is no express provision in criminal law on sexual gratification. It has become a blind spot for legal punishment. Because of that, it should be regulated by law as soon as possible.

\footnotetext{
${ }^{1}$ Henry Campbell Black et al., Black's Law Dictionary (St. Paul, Minnesota: West Publishing Co., 1990), 27.

${ }^{2}$ Syed Hussein Alatas, Corruption: Its Nature, Causes, and Functions (Aldershot, UK, and Brookfield, VT, US: Avebury, 1990), 81.

${ }^{3}$ Tim Redaksi Kamus Besar Bahasa Indonesia, Kamus Besar Bahasa Indonesia, 3rd ed. (Jakarta: Balai Pustaka, 2005), 371.
} 
Sexual gratification has become a crucial problem in Singapore, start from a police official, a minister and even the lecturer who give the best score to his student that paid by sexual service. Moreover, we know that Singapore has been well known as the country with the littlest corruption of Asia.

Malaysia has different cases, the judge set 4 people free who accused accept gratification from a businessman to ease his project. The four people who accused has known that ask a woman to accompany them to a villa at Subang on February 2003. Because it is difficult to prove this case, the judge just set them free. 4

In Indonesia, sexual gratification is uncommonly term but crowded in action. Permadi as one of the houses of representative said that every civil servant or state caretaker who goes for the official job has offered sexual service absolutely; it depends on their mentality for accepting or refusing sexual gratification offering. ${ }^{5}$

On Islamic law, sexual gratification is not only rishwah but also includes into jarīmah al-zinā. Sexual gratification has not been common in Prophet era, Therefore, the hadith about rishwah or gratification related to the things or money, but in the globalization era, the developing of technology is also support the developing of crime. Therefore, many centuries ago, or even in the prophet era, we find rishwah which related to the money or things, nowadays, we find a new case of rishwah that related to a sexual relationship.

About the sexual gratification, the writer interests to write about this case, because there are many sexual gratification cases that happened in Indonesia, and there has not been a specific rule about this case. Therefore, we need deep analysis to find the rule and the punishment whether in positive or Islamic law about sexual gratification.

\section{Gratification in the Islamic Jurisprudence}

Gratification is one of corruption which has done by civil servants and the executive of this nation, but that's problem has not touched yet by law. Even, in the reality that's matter influences them in doing their duty and obligation.

\footnotetext{
4“Gratifikasi Pelayanan Seksual," hukum.kompas.com, 2013, accessed April 17, 2017. http://hukum.kompas.com/2013/01/14/gratifikasi-pelayanan-seksual-524246.html .

5tvone.news, accessed April 17, 2017, www.tvone.news.tv .
} 
W.J.S. Poerwadaminta mentioned that gratification is a gift that given to the civil servant more than the salary which has determined. Based on the Constitution, on Article 12 B and 12 Number 20 the Year 2001, gratification means giving in the wider sense of definition which involves money, goods, discount, commission, a loan with no interest, traveler check, overnight facility, tourism journey, free medication, and other facilities. Gratification may be received within the host country or the foreign country and can be given by electronic or by manual. In the form above, gratification includes transactive corruption.

Firstly, gratification or giving a gift is permitted; even giving a gift was becoming a good tradition long ago. But, nowadays because of developed technology and varieties of social life pattern, gratification or giving a gift was abused by someone who has determined goal. So gratification lost its pure meaning. And because of it, nowadays gratification is prohibited.

Gratification tends to happen in providing things and service factory which involve the government. People abuse gratuities and have a great intention to reach an agreement with the government easily, to succeed in the project. Giving which can indicate into gratification are: giving a gift as repayment for help, giving a free ticket for a holiday to the civil servant, giving a free parcel to the civil servant, giving a free discount for the civil servant, and giving a souvenir to the civil servant in a work tour. This example showed that giving a gift which includes into gratification is, giving which related to a position of a civil servant or workship relationship.

Based on Islamic law, gratification has the same meaning as bribery, or in Arabic called rishwah. Etymologically, rishwah derived from rashā-yarshū, it has the mașdar rishwah, rashwah or rushwah which has meaning al-ja'lu (salary, reward or bribery).7 Terminologically, rishwah is the things given for justifying the wrong and blaming the truth. ${ }^{8}$

6W.J.S. Poerwadarminta, Kamus Umum Bahasa Indonesia, 3rd ed. (Jakarta: Balai Pustaka, 2006).

${ }^{7}$ M. Nurul Irfan, Korupsi dalam Hukum Pidana Islam (Jakarta: Amzah, 2012), 89.

8Ibrāhīm Anīs et al., al-Mu'jam al-Wāsiț juz 1 (Cairo: Dār al-Ma'ārif, 1972), 348.

100 || Vol 28, No. 1, April 2018

AL-AHKAM 
According to Abdullāh bin 'Abd al-Muhsīn al-Ṭāriqiy, rishwah is the things which given for being tools for attaining desire related to position, and wealth. ${ }^{9}$ From the definition, we can conclude that rishwah or gratification has 3 elements: the giver (al-rāshì), the one who accepts (al-murtashī) and the object of rishwah (al-murshā lah).

There are some verses in the Qur'an and Hadith explained about the prohibition of rishwah:

"And eat not up your property among yourselves in vanity, nor seek by it to gain the hearing of the judges that ye may knowingly devour a portion of the property of others wrongfully." (QS. al-Baqarah:188)

The hadith is narrated by Ahmad and Abu Dawūd from 'Abd-Allah ibn 'Amr who said: The Messenger of Allah (peace and blessings of Allaah be upon him) cursed the one who gives a bribe and the one who takes it.

Rishwah whether in Qur'an or hadith is prohibited deeds, it includes to the al-ma'șiyyah (prohibited deed by Allah). The verse 188 of Surah al-Baqarah explained and showed that rishwah or gratification is harām. It showed by using fíl muḍāri' followed by lā nahiy. The qāidah ușūliyyah said: "al-nahyu 'inda 'l-ițlāq yaqtaḍī al-tahrīm (absolutely Prohibition means ḥarām).10

There is no specific regulation about punishment of rishwah that is called by Jarimah Ta'zir. It's become consequent of against Islamic regulation and consequent of disobeying to Allah. Therefore, rishwah must be given assertive punishment for saving others from the suspect and deleting a bribery culture. Abu Said al-Khudri said: "I heard Rasūlullāh said: "Anyone who sees the munkar (something prohibited) then let him prevent with his hand, if he can not, then with his tongue and if he can not (also), then with his heart. That is the weakestweak faith." (HR. Muslim, al-Tirmidhī, al-Nasā'ī, and Ahmad). The government is the one who has the authority to prevent it. Therefore Jarimah Ta'zir is suitable for becoming the punishment of rishwah.

\footnotetext{
9‘Abdullāh bin 'Abd al-Muhsīn al-Tāriqiy, Jarīmah al-Rishwah fi al-Sharīah al-Islāmiyyah ma'a Dirāsah Nizām Mukafahah al-Rishwah fi al-Mamlakah al-Arabiyyah al-Su'üdiyyah (Mesir: alMukarram, 1999), 50.

${ }^{10}$ Asmawi, Teori Maslahat dan Relevansinya dengan Perundang-Undangan Pidana Khusus di Indonesia (Jakarta: Badan Litbang dan Diklat, Kementerian Agama RI, 2010), 131.
} 
According to M. Nurul Irfan, on reality, rishwah is not only involved by three elements, but it can also involve another element such as a broker who became an intermediary between the first party and second party, and person who write the agreement.11

\section{Sexual Gratification: Definition, History dan Factor}

Definition of sexual gratification is giving illegal sexual facilities. The sexual gratification is given to the official or civil servant. The gifts that are not related to their rights and duties. Other definition, sexual gratification is kind of bribing that use a woman as the object, given to the civil servant that related to their position, the aim of giving is to be the winner of thunder or escape from the cases. ${ }^{12}$

Ganjar Laksamana Bondan who is the expert in Law from Indonesian University said that sexual gratification is only the addition of bribe. The main bribe is related to money and things. ${ }^{13}$ The warm discussion on this society is about sexual gratification as a new form of gratification. Moh. Mahfud MD said that sexual gratification is kind of terrible corruption than corruption or gratification by money. ${ }^{14}$

The chief of PBNU, Said Agil Siraj said that sexual gratification is a heinous crime. It does not include only an element but double elements which contained in sexual gratification. Assertively, he said that sexual gratification is not only harmful to Indonesia but will damage nation character. ${ }^{15}$

In summary, sexual gratification is one of a new style of corruption, this case has not been written on UUPTK clearly but entered in Article 12B UUPTK on its explanation impliedly. If the regulation does attention to what implied in

\footnotetext{
11M. Nurul Irfan, Gratifikasi dan Kriminalitas Seksual dalam Hukum Pidana Islam (Jakarta: Amzah, 2014), 12.

${ }^{12}$ Jamal Wiwoho, "Menyoal Gratifikasi Seks dalam Tindak Pidana Korupsi," Media Indonesia, February 7, 2013, http://jamalwiwoho.com/wp-content/uploads/2013/02/gratifikasi-sex.pdf.

13Tempo.co, "Gratifikasi Seks Menjadi Pelengkap Suap," Nasional Tempo.co, 2013, https://nasional.tempo.co/read/490318/gratifikasi-seks-menjadi-pelengkap-suap.

${ }^{14}$ Wiwoho, "Menyoal Gratifikasi Seks."

15Zul, "KH Said Aqil: Gratifikasi Seks Kategori Zina, Hukumannya Harus Lebih Berat," RMOL.co, 2013, https://www.rmol.co/read/2013/01/15/94140/KH-Said-Aqil:-Gratifikasi-Seks-KategoriZina,-Hukumannya-Harus-Lebih-Berat-.
} 
every rule, sexual gratification must be punished. Unlucky, only corruption and gratification which related to the things and money which be punished.

Corruption has begun at the beginning of life. When the society has been crowded, a human has been bothering with corruption as thousand years ago. Intensity and kind of corruption tend to differ in everytime and everyplace. Corruption especially the gratification one has been crowded problems in Egypt, Babilonia, India, China, Ibrani, and Roma long ago, the leader of Babilonia, Hammurabi, asked the governor to investigate some gratification cases. ${ }^{16}$

On revolution era (1945-1950), Indonesia has been fulled by stories of the greatest author like, Pramoedya Ananta Toer (Di Tepi Kali Bekasi), and Mochtar Lubis (Maut dan Cinta), we often read about the one who takes profit, while others do struggle hard for making country independence. ${ }^{17}$ Time goes by, the rule about corruption is created. The crucial problem is on the way to overcome and wipe out. The Corruption Eradication Commission (KPK) as the only trusted institution to overcome corruption now.

Seeing the history, corruption is one of democracy product due there is no democratic country which has been free from corruption. After 13 years ago, reformation of politic bureaucracy cannot eliminate of corruption tradition. The bureaucracy of reformation holds on repairing government system through transparency mechanism. The reality, the members of bureaucracy inhibit the success of clean bureaucracy and government system.

In addition, the proliferation of corruption, especially gratification is caused by weak enforcement by officials who are trusted to eradicate corruption, such as the Corruption Eradication Commission (KPK), Tipikor court, and others. Therefore the suspect more glorious to do his action, and even corruption became of democracy fuel.

The factors that cause sexual gratification are almost the same as the factors that cause corruption. Syed Hussein Alatas said that cause of corruption is increasing amount of civil servant. By increasing amount of civil servant, it means increasing authority and chance of bureaucracy while a weak of

\footnotetext{
${ }^{16}$ Syed Hussein Alatas, Korupsi: Sifat, Sebab dan Fungsi, translated by Nirwono (Jakarta: LP3ES, 1987), 1.

17Ajip Rosidi, Korupsi dan Kebudayaan (Jakarta: PT Dunia Pustaka Jaya, 2006), 24.
} 
supervision and influencing from a political party. ${ }^{18}$ According to Krisna Harahap, there are internal and external factors. The internal factors are: first, an impulsing necessity which means someone accept gratification due to their salary amount less than necessity. Second, impulsing of greed means someone accepts gratification to create luxurious life. The external factors are an environment which considers that gratification is a common deed, besides there is a big opportunity due to supervision weakness about gratification. ${ }^{19}$

According to the transparency international society, sexual gratification can happen because the lowness willing of government to overcome the problem. ${ }^{20}$ This is evidenced by the weak enforcement of the authorities, especially in the political sector. Therefore, will be less of maintaining for the people who broke the law especially sexual gratification.

According to Ilham Gunawan, the causes of sexual gratification are decreasing morality and ethics, colonialism, education weakness, poverty, weakness of government policy, and unassertive of government structural. ${ }^{21}$

According to the author, one of the sexual gratification factors is lowness of understanding religion. As same as Nurul Irfan argument, if someone has been a strong faith, little Possibility to do sexual gratification. ${ }^{22}$ Besides that, decreasing qualification of requirements for recruitment civil servant also becomes the factor of sexual gratification. Someone who has not a good mentality, who became a civil servant or minister, for example, face a big opportunity and big chance to do corruption, he will do, because there is a big chance while no balanced by a good mentality.

\section{Cases and Law Enforcement of Sexual Gratification in the Some Countries}

Sexual gratification happened along ago in many countries; Singapura, Malaysia, South Korea, and even Indonesia. Sutan Bathoegana one member of

\footnotetext{
18Syed Hussein Alatas, Korupsi: Sifat, Sebab dan Fungsi, 122.

${ }^{19}$ Krisna Harahap, Pemberantasan Korupsi Jalan Tiada Ujung (Bandung: Grafiti, 2006), 7-8.

20Surachim and Suhandio Cahaya, Strategi dan Teknik Korupsi: Mengetahui Untuk Mencegah (Jakarta: Sinar Grafika, 2011), 107.

21Surachim and Cahaya, Strategi dan Teknik Korupsi, 108.

22Irfan, Korupsi dalam Hukum Pidana Islam, 37.
} 
Comite III DPR RI said that sexual gratification happened long ago in many countries for example Singapura. ${ }^{23}$ In Singapura, sexual gratification has become a crucial problem. Start from a police official, minister and even the lecturer who will give the best score for his student that paid by sex service. Moreover, we know that Singapura has been well known as the country with the littlest corruption of Asia.

In Singapura, some of the sexual gratifications has been punished by the government. On 2011, director at Singapore drug center (CNB), Ng Boon Gay was asked to go to the court cause of accepting sexual gratification from Cecilia Sue Siew Nang. Ng Boon Gay admitted has accepted sexual gratification four times from Cecilia for succeeding IT project. He was punished on December 2011.

Other cases, member of Police Singapore, Sersan Pathivan Ramaya and Investigator on the ministry of Labor, Norezwan Em. Sersan Pathivan was punished because giving remission for stealing cases as the recompense of sexual gratification from Dwi Sulistiani. Norezwan Em accepted sexual gratification from Liu Lihua citizen of China for an extension of the resident permit in Singapura. Both of them, threaten by jailing a maximum 5 years, and a fine maximum 1000.000 dollar Singapore or about 800 million. ${ }^{24}$

Singapore Senior Minister of State for Foreign Affairs and Home Affairs, Masagos Zulkifli said that in Singapore, everyone, who accept everything whether money, things, or service, he must pay off and collecting a half of his salary, that's the consequence of doing gratification. ${ }^{25}$

Three arbiters from Lebanon accused has accepted sexual gratification, for success league score of one group. Three arbiters were leading AFC Cup 2013 competition between Singapore club Tampines Rovers and East Bengal from India. All of the arbiters directly changed with another arbiter after caught by the Corrupt Practices Investigation Bureau (CPIB) with accusation has accepted sexual gratification. ${ }^{26}$

\footnotetext{
23tvone.news, accessed October 17, 2017, www.tvone.news.tv.

24“Sexual Gratification Service," n.d., http://IIr.or.id/ sexual gratification service

${ }^{25} \mathrm{http}: / /$ news.detic.com/hukum antigratifikasialasingapura ( access on June 6, 2017).

26 //www.googletagmanager.kompas.com (access on November 1, 2017).
} 
One of a main agency colonel of Singapore, Singapore Civil Defense Force (SCDF) Peter Lim, has accepted sexual gratification from 3 women as his partners. Sexual gratification which has accepted as repayment of project technology and information contract on the women enterprise.

Peter has been caught by Corrupt Practices Investigation Bureau (CPIB) on January 2012 and on February, he asked to resign from his position. Three women were given sexual gratification hold a high position in every business. They are Pang Chor Mui as general manager Nimrood Engineering, Lee Wei Hoon, as the director of radiation center of Singapore and Esther Goh as director of developing business NCS Private Limited. Peter Lim has admitted that he did sexual gratification in a different place with different women. Such as Big Splash East Coast Park, Singapore Indoor Stadium and a luxurious hotel in France.

Malaysia has a different case, The judge set 4 people free who accused accept gratification from a businessman to ease his project. The four people who accused has known that ask a woman to accompany them in the villa at Subang on February 2003. Because difficult to prove this case, the judge just set them free. ${ }^{27}$

In Indonesia, Sexual gratification is uncommonly term but crowded in action. Permadi as one of the houses of representative said that every civil servant or state caretaker who goes for the official job has offered sexual service absolutely, it depends on their mentality for accepting or refusing sexual gratification offering. ${ }^{28}$

The example cases gratification which indicated by sexual services are:

Ahmad Fathonah as the close friend of the chief of PKS many years ago, Lutfi Hasan, caught by KPK in Le Meridien hotel with Mariana Suciono one of a student in one of the famous university in Jakarta. KPK also found a bundle of money IDR 10.000.000 as recompense becoming escort lady ${ }^{29}$ from that cases, the identification is too difficult without balancing by the strong regulation of this country.

\footnotetext{
27 "Gratifikasi Pelayanan Seksual."

${ }^{28}$ www.tvonenews.com (access on April 16, 2017)

${ }^{29}$ Escort Lady comes from Italy. Escort means guard. Escort lady assign by her boss to accompany the guest's boss for dinner and doing project in the night time. But day by day escort lady abuse their profesion to the negative way as called woman.
} 
In 2008, one of member of DPR RI, Al-Amin Nur Nasution caught by KPK in Pub Mystere Hotel Ritz Carlton cause of sexual gratification case. Al-Amin accompanied by a beautiful woman which accused as "a gift" from regency secretary of Bintan. Al-Amin has accepted sexual gratification as repayment for helping nature preserve business of Bintan Island. Al-Amin Nasution declared as the suspected of sexual gratification has broke chapter 12a and 12e Law No. 31 of 1999 as amended by Law No. 20 of 2001 on Corruption Eradication by jailing 15 years and find 500 million. On next court, the judge decided based on chapter 11 and 12 e Law No. 31 of 1999 as amended by Law No. 20 of 2001 on Corruption Eradication by sentenced Al-Amin to jail along 8 years and fine 250 million. ${ }^{30}$

On higher decision on the next step which decided by the high court, punishment increase into jail 10 years by considering transcript dialogue between the suspect and others about asking to look for a good woman. There was a negotiation about woman criteria. A final decision on causation the punishment decrease in 8 years, it showed that transcript dialogue about a woman suitable to consider in giving punishment.

On 2013, Setyabudi Tejo Cahyono, Judge of the district court of Bandung has accepted gratification from Toto Hutagalung, it's about 3 billion, for decreasing punishment of corruptor social funding for eliminating the name of Edi Eswadi as ex-mayor and regional secretary of Bandung. ${ }^{31}$

Toto Hutagalung as the chief of Gasibu Padjajaran is the soulmate of Dada Rosada, governor of Bandung. They admitted that asked to provide sexual services often by Setyabudi. Johnson Siregar, as the lawyer of Toto Hutagalung, explained to the team of corruption eradication commission that, Setyabudi was not only asked money for gratification but also sexual service. ${ }^{32}$

Toto Hutagalung gave addition that every Friday night, Setyabudi asked karaoke service beside asking money and asking a woman to entertain him.

30Tim Liputan, “Insert: Layanan Seks Bisa Masuk Gratifikasi,” January 8, 2013, https:// www. haluankepri.com/readdetail/40302/layanan-seks-bisa-masuk-gratifikasi-. Access on Augt15, 2017.

31Ikatan Hakim Indonesia (IKAHI), Varia Peradilan Majalah Hukum XXIX, no. 344 (2014): 72.

32Dewi Novita Sari, "Tindak Pidana Korupsi dalam Bentuk Gratifikasi Seksual," Lex Crimen 2, no. 3 (2013): 176, https://ejournal.unsrat.ac.id/index.php/lexcrimen/article/view/2439/1976. 
According to Toto, karaoke service can spend more than 25 million.33 Prosecutor has prosecuted Setyabudi and snatched him with chapter $12 \mathrm{C}$, Chapter 6a and Chapter 12a, Law No. 31 of 1999 as amended by Law No. 20 of 2001 on corruption eradication, by jailing 16 years and fine 400 million. Finally, a final decision which decided by a judge sentenced to punishment 12 years and find 200 million. Therefore, for this case, it showed that sexual gratification element is not really considered by the judge. Although there an admission from the witness and suspect. Toto Hutagalung as the witness has said that Setyabudi also asked sexual service beside money.

Izedrik Emir Moeis, a member of DPR RI snatched gratification cases on PLTU project Tarahan, Lampung. On investigation of a witness, Pirooz Sharafi said that Emir has accepted sexual gratification in 2002. Emir, Sharafi and Fred Perruci met the club in Paris and gone out with a beautiful woman who asked by Fred to accompany Emir in Paris. On 2014, Emir Moeis sentenced by the judge, jailing 3 years and fine 150 million. The judge declared that the suspect was broke chapter 11 Law No. 31 of 1999 was amended by Law No. 20 of 2001 of Corruption Eradication. ${ }^{34}$

On October 2014, one of the candidates of a policewoman, initial GS, was known that she is pregnant when doing study process on the police academy. GS was admitted that her pregnancy because giving sexual service for a policeman. She has threatened, if she refuses, she will be eliminated from the candidate of policewoman list. Sexual gratification has given by policewoman as repayment for her success on selection policewoman test. This case showed that sexual gratification has spread out on police agency. The policeman asked sexual service clearly as his repayment for success GS on her test. Policeman deeds related to his position, therefore, policeman deed include into gratification if related to Chapter 12B.

Law enforcement for sexual gratification which has implied in Indonesia is, the judge tends to consider gratification element by money or things, because

\footnotetext{
33“Para Terdakwa Sering Karaokean Bersama," Kompas.com, 2013, http://www.kompas.com/ regional/2013/11/01/para-terdakwa-sering-karaokean-bersama. Acess on November 14, 2017

${ }^{34}$ Tri Artining Putri, "Emir Moeis Disebut Dapat Gratifikasi Seks di Paris," Nasional Tempo.co, 2013, https://nasional.tempo.co/read/534803/emir-moeis-disebut-dapat-gratifikasi-seks-di-paris. Access on September 11, 2017.
} 
sexual gratification element looks different to enter in consideration, because there is no clear regulation, it should be there is explanation more on Law No. 31 of 1999 as amended Law No. 20 of 2001 about eradication of corruption.

The most difficulties to overcome sexual gratification case is, how to prove it. Authentication is one of inhibiting factor in law enforcement. According to $\mathrm{H}$. Ansori, the judge of Ad Hoc in the criminal act of corruption in Maluku, he explained that sexual gratification is really difficult to prove because of a bit of evidence and witness. ${ }^{35}$

Indonesia has not applied the truth of sexual gratification regulation on the national penal law. Although, about gratification has explained in Law No. 31 of 1999 as amended Law No. 20 of 2001 about the eradication of corruption, but unfortunately, there is no effort for entering sexual gratification element clearly into regulation.

Moreover, sexual gratification cases have spread out in every institution and society. The assertiveness of the judge to overcome this case also needed to be the best solution; based on chapter $12 \mathrm{~B}$ actually sexual gratification element has included into gratification and must be punished. Because decreasing assertiveness of the judge and there is no one to start to overcome and brave to punish, therefore another judge to be followers only, who did not to punish sexual gratification.

\section{Sexual Gratification in the Fiqh Jināyāh}

Based on Fiqh Jināyah perspective, gratification is prohibited. Allah curses the one who gave and took gratification.

Rasūlullāh asked 'Abdullāh bin 'Umar for collecting alms (zakat) from Bani Sulaim. 'Abdullāh said, "it's too much for zakāt, how if we divided it into sadaqah?" Rasūlullāh answered, "Stay at your parent's house until the one who gives șadaqah comes if you are truly honest. ${ }^{36}$ In Khulafä' al-Rāshidīn era, Umar bin Khattab asked his entire governor to refuse whatever the kind of gift. Because the gift is a part of bribe or gratification, and he said:

\footnotetext{
35Ikatan Hakim Indonesia (IKAHI), Varia Peradilan Majalah Hukum XXIX, no. 344, 94.

36A. Rahman I.Doi, Penjelasan Lengkap Hukum-hukum Allah (Syariah) (Jakarta: Raja Grafindo Persada, 2002), 505.
} 
Nadea Lathifah Nugraheni

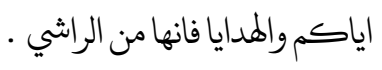

"For you, the gifts are a part of the bribe."

This statement is really true if related to the assumption today. Rishwah is covered by a gift that has common in society. Khalīfah 'Umar bin 'Abd al-'Azīz always refused all of the things that given to him, he said:

$$
\text { كانت له هدية ولنا شوة لانه كان يتقرب اليه لنبوته لا لولايته ونحن يتقرب الينا للولاية. }
$$

"For him, that's a gift, but for us, that's a bribe. Because close to Rasul is due to he is Rasul, is not because of his authority. But they want to close us because of our authority"

Prophet Muhammad ever accepted a gift, then gave to the beggar. In Rasūlullāh era, giving a gift to the author specially Rasūlullāh is not related to own profit intent, but nowadays, there are many kinds of profit intention to close to the author. Prophet Muhammad has reminded that "There was an era where rishwah consider to permitted by a gift and killing by reprimand". ${ }^{37}$ About bribe or gratification in Islam has prohibited clearly, moreover sexual gratification.

Sexual gratification contains double crimes, not only rishwah but also zinā. Zinā is morally the most heinous crime, In Islamic law, zinā is divided into two terms, zinā muhșan (adultery) for the suspect who has been married, zinā ghayru muhșan (fornication) for the suspect who has not been married before. Absolutely It will be implied for different punishment.

Based on Fiqh Jināyah, zinā is divided into two, Adultery and fornication. Adultery is an evil which opens the road to other evils. ${ }^{38}$ Adultery is not only shameful in itself and inconsistent with any self-respect or respect for others, but it induces to invite many other evils. It destroys the basis of the family, it may lead to murders and feuds and loss of reputation and property. Not only should be avoided as a sin but also an approach or temptation to the fornication is should be avoided.

37.Doi, Penjelasan Lengkap Hukum-hukum Allah, 505.

38M. Iqbal Siddiqi, The Penal Law of Islam (New Delhi: Shahid International Islamic Publishers, 1994), 53.

110 || Vol 28, No. 1, April 2018

AL-AHKAM 


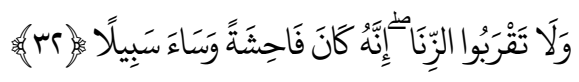

"Nor come nigh to adultery for it is wickedness (shameful deed) an evil path". (QS. al- Isrā': 32)

Fornication is the most heinous crime a person does. the nature of the person doing the obscenity, in fact, can be said that the nature of his humanity has been overwhelmed by his animalistic, and he is not fit to live as a virtuous member of society. Fornication, from a social point of view, is one of the heinous crimes that cut off the roots of civilization. Therefore, Islam considers adultery as a violation that can be punished for its own sake, both accompanied by several other violations such as violence or for the benefit of others.

According to Abdul Malik, sexual gratification includes into jarimah alzinā. ${ }^{39}$ Therefore, based on fiqh jināyah perspective, law position of sexual gratification includes into jarimah al-zinā and rishwah and absolutely includes into a big sin. Threaten punishment for the suspect or the one who accept sexual gratification is for 100 times for the one who is single and rajam for the one who has been married.

Fornication is strict signification implies an illicit sexual relationship between two unmarried persons. The punishment for fornication is one hundred stripes. The Holy Qur'an says:

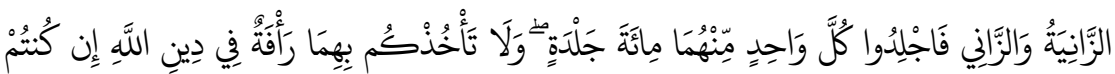

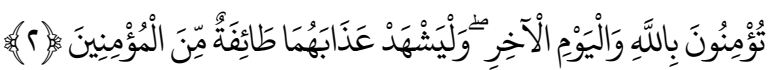

"The fornicators shall each be given a hundred stripes, and let not compassion move you in their case, in a matter prescribed by Allah, if you believe in Allah and Last day: And let a party of the believers witness their punishment." (QS. al-Nūr: 2)

If the person convicted of fornication is a slave, male or female, the punishment of such is only fifty stripes. Because the Holy Qur'an says:

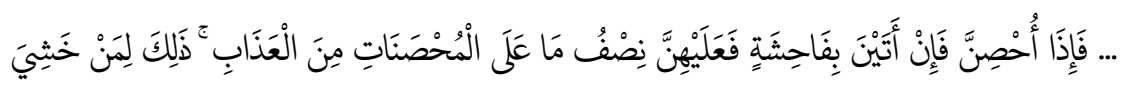

${ }^{39}$ M. Abdul Malik, Perilaku Zina: Pandangan Hukum Islam dan KUHP (Jakarta: Bulan Bintang, 2003), 25. 
Nadea Lathifah Nugraheni

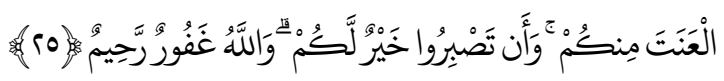

"... And if when they (the slave girl) are honorably married, they are guilty of indecency, they shall incur the half of the punishment (prescribed) for a free woman (in that case)." (QS. al-Nisā': 25)

The authentication of jarimah al-zinā based on fiqh jināyah is four: confession of the suspect four witness who strengthens by swearing proof of pregnancy documents and other forensic evidence. ${ }^{40}$

For response this cases, according to fiqh jināyah, the writer uses double crimes theory, they are nazariyat al-tadākhul (completing theory) and nazariyat al-jabbu (absorption theory). First: completing theory (nazariyat altadākhul), this theory said when double crimes happened; the punishment is completing each other. Therefore, the deeds only give one punishment. The reason for giving one punishment only, for giving ta'dỉb-education or preventing for others society (al-zajru) which both of this aims, can be reached by one punishment only. Second: absorption theory (nazariyat al-jabbu), this theory is giving punishment which other punishment cannot be given because has absorbed by one punishment. The punishment is the death penalty. The death penalty absorbs all of the kind of punishment. According to Imām Shāfi'iy, there is no absorption theory (nazariyat al-jab). All of the punishment must be given. The criminal act which related with the human rights became a priority. After that, the criminal action which related to Allah's right Third: mixing theory (al-mukhtalat) which uses for overcoming the weakness of the previous theory, completing and absorption theory. Gathering both of the cases and look for the center way. ${ }^{41}$ This theory is the suitable theory to analyze deeply to the sexual gratification cases: the sexual gratification is punished by mixing theory (al-mukhtalat) which gives the punishment mixed. Jarimah ta'zir as the punishment for rishwah, must be first priority cause it is related to the human rights. But zinā is related to Allah's right, this is according to Imām Shāfi'iy. Allah's right must be implemented after human right. After human rights have been done, punishment for jarimah al-zinā may do to the suspect of sexual gratification. This theory is suitable which appropriates for

40Malik, Perilaku Zina: Pandangan Hukum Islam dan KUHP, 273-274.

41Ahmad Hanafi, Asas-asas Hukum Pidana Islam (Jakarta: Bulan Bintang, 2005), 57.

112 || Vol 28, No. 1, April 2018

AL-AHKAM 
human rights and doesn't ignore Allah's right. This punishment is suitable enough for the Islamic state or even the region such as Aceh, which implemented Islamic law purely. Sexual gratification must be punished heavily because it's a deed related to the moral nation.

\section{Sexual Gratification in The Positive Law}

Based on the constitution, on Article $12 \mathrm{~B}$ the giving object is common by something which has meaning and others which has value and usability for a human. The words "thing" can be material or immaterial things. The material things mean transferring ownership for the things to who accepted. The immaterial things mean transferring authority over things such as facility and service. It means, which move is not the shape of things but the authority of the things. ${ }^{42}$

In Chapter 209 KUHP which adopted into Chapter 5, Chapter 418 which adopted into Chapter 11 and Chapter 419 KUHP which adopted into Chapter $12 \mathrm{a}$ and $\mathrm{b}$. The word "giving a thing" in Chapter 5 Moreover, the word giving "a gift" (hadiah) comes from the same root, that's the word "a gift" which has meaning "hadiah". The word "gift" is included into noun, it means, a gift is a thing.

The word "gift" on Chapter 418 KUHP which adopted in Chapter 11 gave the addition on the word "gift" to be giving a gift. Back to the definition of elements on Chapter 5, the word "gift" or "things" it can be immaterial things such as, service, facility, and ease that include into gratification on Chapter 12B.

According to Adami Chazawi, distinguish between gratification and giving a gift is can truly be detected, for example, a man who has big intention to solve his project, he gave beautiful woman to the civil servant for accompanying him in the other country for a week. This case is impossible to be called giving such a usual gift, sure it includes into gratification. ${ }^{43}$

Hoge Raad (Supreme Court of Dutch) on 25 April 1916 said that "Giving a gift in this chapter not only cause of generosity but also balanced by having a

\footnotetext{
42Mahrus Ali, Asas Teori dan Praktek Hukum Pidana Korupsi (Jakarta: Umpress, 2010), 126-27.

${ }^{43}$ Adami Chazami, Hukum Pidana Materil dan Formil Korupsi di Indonesia (Surabaya: Hidayah, 2011), 170-71.
} 
profit for the one who will accept." 44 This statement explained that bribe or gratification is impossible caused by the generosity and valuable things are based on public perspective, is not subjective into the giver or the one who accept. This decision gives an answer for the debatable object of gratification, that the object is not only material things, but immaterial things also, Therefore, sexual gratification is not included into Chapter 12B UU Tipikor, but also Chapter 5 and $12 \mathrm{a}$ and $\mathrm{b}$.

Based on positive law punishment of the suspect sexual gratification can be punished by Chapter 5 verse 2, Chapter 12a and 12b Chapter 12B UU No.31/1999 Jo. UU No. 20/2001. For the giver, is punished by Chapter 5 verse 1. For the object of gratification (escort lady) can be punished by Chapter 15 contains trial, help an evil conspiracy. Elements of Chapter 15 have same contents with Chapter 1 verse 2 UU No. 3 The year 1971 which explained that "Because of corruption is really destruct economy of the nation, therefore trial to do corruption is also threatened by punishment which same by corruptor." Not only trial but also evil conspiracy to do corruption is will be punished. Chapter 15 includes special regulation. Commonly, the punishment of trial in crime less $1 / 3$ than the origin punishment ${ }^{45}$ Therefore, the object of sexual gratification can be punished by Chapter 5 verses 1 UU Corruption. As the one who helps the giver of gratification, she can be punished the same as the corruptor.

In the mind of society, authentication of sexual gratification is looked difficult, but actually authentication of sexual gratification as same as authentication of other crimes. Based on Chapter 184 KUHP, require area confession of the witness, the expert, and the suspect and also documents and instructions. The requirements minimal are showing two proofs.

The example cases, a businessman on 2 Mei 2010 gave a beautiful girl to the governor for influencing his business to get SK (decision letter) from the governor. A businessman asked the beautiful girl to flatter the governor and

\footnotetext{
${ }^{44}$ P.A.F. Lamintang, Delik-delik Khusus Jabatan Tertentu sebagai Tindak Pidana Korupsi (Jakarta: Sinar Grafika, 2011), 309.

45R. Wiyono, Pembahasan Undang-Undang Pemberantasan Korupsi (Jakarta: Umpress, 2011), 134-35.
}

114 || Vol 28, No. 1, April 2018 
check into the hotel. The businessman gave some money (10 million) to the beautiful girl as the honorarium on 1 Juni 2010, the governor gave SK to the businessman for his factory.

In that case, the proofs are decision letter, 10 millions of money, receipt of staying at the hotel and the confession of a beautiful girl. The society considers gratification has not been regulation clearly, moreover, there are many cases that done by a civil servant. But, actually, KPK has regulated in the constitution of gratification even sexual gratification.

The true solution is the government must analyze and include the sexual gratification into Chapter 12B Law No. 20 of 2001 as the corruption act. The regulation should be clear, because sexual gratification is really different, whether in the object or even punishment.

\section{Conclusion}

The gratification has been regulated on Law No. 31 of 1999 as amended No. 20 of 2001 about the eradication of corruption. Specifically, in Chapter 12B. The problem is the regulation has not been clear. The regulation has not clear for mentioning sexual gratification includes into gratification as corruption act. The regulation only mentions things which include into gratification, they are money, goods, discount, commission, a loan with no interest, traveler check, overnight facility, tourism journey, free medication, and other facilities.

While in the Fiqh Jināyah perspective, sexual gratification includes double crimes, rishwah, and zinā. And theory (al-Mukhtalat) is the suitable theory to analyze deeply to the sexual gratification cases: the sexual gratification is punished by mixing theory (al-Mukhtalat) which give the mixed punishment.

This comparative study between Fiqh Jināyah and the positive law has explained that both of them are different in the definition and even punishment. In the Fiqh Jināyah perspective, sexual gratification has destructed human's right, through embedding society's money. Not only that but also broke Allah's right through zinā which prohibited by naș. Basically, both of them agree to prohibit sexual gratification for keeping Indonesian character and nation.[a] 


\section{BIBLIOGRAPHY}

Alatas, Syed Hussein. Corruption: Its Nature, Causes, and Functions. Aldershot, UK, and Brookfield, VT, US: Avebury, 1990.

-_- Korupsi: Sifat, Sebab dan Fungsi. translated by Nirwono. Jakarta: LP3ES, 1987.

Ali, Mahrus. Asas Teori dan Praktek Hukum Pidana Korupsi. Jakarta: Umpress, 2010.

Anīs, Ibrāhīm. al-Mu'jam al-Wāsiț. Cairo: Dār al-Ma'ārif, 1972.

Asmawi. Teori Maslahat dan Relevansinya dengan Perundang-undangan Pidana Khusus di Indonesia. Jakarta: Badan Litbang dan Diklat, Kementerian Agama RI, 2010. https://catalogue.nla.gov.au/Record/ 5154284 .

Black, Henry Campbell, Joseph R. Nolan, Jacqueline M. Nolan-Haley, M. J. Connolly, Stephen C. Hicks, and Martina N. Alibrandi. Black's Law Dictionary. St. Paul, Minnesota: West Publishing Co., 1990.

Chazami, Adami. Hukum Pidana Materil dan Formil Korupsi di Indonesia. Surabaya: Hidayah, 2011.

Dewi Novita Sari. "Tindak Pidana Korupsi dalam Bentuk Gratifikasi Seksual." Lex Crimen 2, no. 3 (2013): 173-84. https://ejournal.unsratac.id/ index.php/lexcrimen/article/view/2439/1976.

“Gratifikasi Pelayanan Seksual." Hukum.Kompas.Com, 2013. http://hukum. kompas.com/2013/01/14/gratifikasi-pelayanan-seksual-524246.html.

Hanafi, Ahmad. Asas-asas Hukum Pidana Islam. Jakarta: Bulan Bintang, 2005.

Harahap, Krisna. Pemberantasan Korupsi Jalan Tiada Ujung. Bandung: Grafiti, 2006.

I.Doi, A. Rahman. Penjelasan Lengkap Hukum-hukum Allah (Syariah). Jakarta: Raja Grafindo Persada, 2002.

Ikatan Hakim Indonesia (IKAHI). "No Title." Varia Peradilan Majalah Hukum XXIX, no. 344 (2014).

Irfan, M. Nurul. Gratifikasi dan Kriminalitas Seksual dalam Hukum Pidana Islam. Jakarta: Amzah, 2014.

__—. Korupsi dalam Hukum Pidana Islam. Jakarta: Amzah, 2012. 
Lamintang, P.A.F. Delik-delik Khusus Jabatan Tertentu sebagai Tindak Pidana Korupsi. Jakarta: Sinar Grafika, 2011.

Malik, M. Abdul. Perilaku Zina: Pandangan Hukum Islam dan KUHP. Jakarta: Bulan Bintang, 2003.

"Para Terdakwa Sering Karaokean Bersama." Kompas.com, 2013. http://www. kompas.com/regional/2013/11/01/para-terdakwa-sering-karaokeanbersama.

Poerwadarminta, W.J.S. Kamus Umum Bahasa Indonesia. 3rd ed. Jakarta: Balai Pustaka, 2006.

Rosidi, Ajip. Korupsi dan Kebudayaan. Jakarta: PT Dunia Pustaka Jaya, 2006.

"Sexual Gratification Service," n.d.

Siddiqi, M. Iqbal. The Penal Law of Islam. New Delhi: Shahid International Islamic Publishers, 1994.

Surachim, and Suhandio Cahaya. Strategi dan Teknik Korupsi: Mengetahui Untuk Mencegah. Jakarta: Sinar Grafika, 2011.

al-Ṭāriqiy, 'Abdullāh bin 'Abd al-Muhsīn. Jarīmah al-Rishwah fi al-Sharī'ah alIslāmiyyah ma'a Dirāsah Niz̄ōm Mukafahah al-Rishwah fi al-Mamlakah al-'Arabiyyah al-Su'ūdiyyah. Mesir: al-Mukarram, 1999.

Tempo.co. “Gratifikasi Seks Menjadi Pelengkap Suap.” Nasional Tempo.co, 2013. https://nasional.tempo.co/read/490318/gratifikasi-seksmenjadi-pelengkap-suap.

Tim Liputan. "Insert: Layanan Seks Bisa Masuk Gratifikasi,” 2013. https:// www.haluankepri.com/readdetail/40302/layanan-seks-bisa-masukgratifikasi-.

Tim Redaksi/Penyusun. Kamus Besar Bahasa Indonesia. 3rd ed. Jakarta: Balai Pustaka, 2005.

Tri Artining Putri. "Emir Moeis Disebut Dapat Gratifikasi Seks Di Paris." Nasional Tempo.co, 2013. https://nasional.tempo.co/read/534803/ emir-moeis-disebut-dapat-gratifikasi-seks-di-paris.

tvone.news. "No Title." Accessed October 17, 2017. www.tvone.news.tv.

Wiwoho, Jamal. "Menyoal Gratifikasi Seks dalam Tindak Pidana Korupsi.” Media Indonesia. February 7, 2013. http://jamalwiwoho.com/wpcontent/uploads/2013/02/gratifikasi-sex.pdf.

Wiyono, R. Pembahasan Undang-Undang Pemberantasan Korupsi. Jakarta: Umpress, 2011. 
Nadea Lathifah Nugraheni

Zul. "KH Said Aqil: Gratifikasi Seks Kategori Zina, Hukumannya Harus Lebih Berat." RMOL.co, 2013. https://www.rmol.co/read/2013/01/15/ 94140/KH-Said-Aqil:-Gratifikasi-Seks-Kategori-Zina,-HukumannyaHarus-Lebih-Berat-. 